\title{
METAL EVALUATION AND ECOTOXICOLOGICAL BIOASSAYS USING Chironomus xanthus in SEDIMENTS OF TRIÂNGULO MINEIRO WATERCOURSES
}

\author{
AVALIAÇÃO DE METAIS E BIOENSAIOS ECOTOXICOLÓGICOS UTILIZANDO \\ Chironomus xanthus EM SEDIMENTOS DE CURSOS DE ÁGUA DO TRIÂNGULO \\ MINEIRO
}

\author{
Renata de Moura GUIMARÃES-SOUTO' ${ }^{1}$; Juliano J. CORBI ${ }^{2}$; Giuliano Buzá JACOBUCCI ${ }^{1}$ \\ 1. Universidade Federal de Uberlândia, Uberlândia, MG, Brasil. guimaraesrm@gmail.com; 2. Universidade de São Paulo, São Carlos, \\ SP, Brasil.
}

\begin{abstract}
This study aimed to evaluate metal contamination in sediments of the Triângulo Mineiro watercourses and also analyze the toxicity of the sediments using Chironomus xanthus larvae, as test organisms. We collected sediments from three streams (P1, P2 and P3) and collected sediments in three points of the Uberabinha River (P4, P5 and P6). We analyzed $\mathrm{Cu}, \mathrm{Cr}, \mathrm{Mn}, \mathrm{Mg}$ and $\mathrm{Zn}$, and also performed acute and chronic toxicity tests. Acute tests were categorized into toxic (death $>50 \%)$, toxicity signs $(10<$ mortality $<50 \%)$ and non-toxic (mortality $<10)$, according to common protocols. In the chronic toxicity tests, the surviving larvae were stored for body size measurements. Of the five metals analyzed, all were found in the six sampling points, but only $\mathrm{Cu}$ and $\mathrm{Zn}$ were present at higher levels than the "Threshold Effect Level" (TEL). The sediments of the six sites have some level of toxicity and the mortality in the acute and chronic toxicity tests was $100 \%$. No statistically significant differences, between treatment and the control were found in the larval growth. Based on the metal contamination and the toxicity bioassay results, we consider it important to monitor sediments and to evaluate changes in land use in the adjacent water courses.
\end{abstract}

KEYWORDS: Acute toxicity. Chronic toxicity. Body size and zinc.

\section{INTRODUCTION}

The contamination of aquatic ecosystems by xenobiotic compounds has increased in recent years because of anthropogenic impacts (ARIAS et al., 2007). The main point sources of water pollution are domestic waste and chemical residues of industrial and agricultural activities (MATEO-SAGASTA et al., 2016). Agricultural systems are the principal source of disturbances in water ecosystems (PARRIS, 2002). Among the main impacts are the distinct soil erosion, deforestation and non-point water pollution by fertilizer and pesticide residues (ZIA et al., 2013; CORBI et al., 2018). Water pollution represents risks to aquatic ecosystems and human health (UNEP, 2016).

Several fertilizers contain in their composition different concentrations of lead, nickel, chromium, cadmium and zinc that, due to soil runoff process, reach the adjacent water systems (CORBI et al., 2010). This situation becomes more serious in the absence of riparian vegetation, which can minimize the surface runoff of toxic substances into aquatic environments (ANGELOTTI-NETTO et al., 2004; AMBUMOZHI et al., 2005; CORBI et al., 2006;). The toxicity of metals can be observed at the individual level, for example, increasing the mortality rate of the most sensitive species and altering other important processes such as growth and reproduction (CASPER, 1994; AMISAH; COWX, 2000).

Considering the input of metals into aquatic ecosystems and their deleterious effects on aquatic fauna, for high concentrations it becomes important to monitor the presence in and effects of these compounds on aquatic organisms. Toxicological tests are an important tool for monitoring and are designed to assess the toxicity of substances, industrial effluents and environmental samples (water and sediment). Test-organisms are exposed to different concentrations of a sample and toxic effects are observed and quantified (COSTA et al., 2008). Acute toxicity tests are used to measure the effects of toxic agents on test organisms over a short period of time relative to the life cycle of the test species (COSTA et al., 2008), which can be determined by lethal concentration (LC50). Chronic toxicity tests are used to evaluate the potential toxic effects of chemicals under conditions of prolonged exposure to sub-lethal concentrations, that allow the survival of organisms, but which affect their biological functions, such as reproduction, egg development and growth (BUIKEMA; VOSHELL, 1993; BAPTISTA et al., 2002; COSTA et al., 2008).

Sediments are important compartments of aquatic environments, since they can accumulate 
substances such as metals and pesticides, becoming a sink of these elements. However, under certain environmental conditions such as changes in $\mathrm{pH}$ and conditions of anoxia, sediment can release toxic substances into the water column, causing disturbances in the aquatic systems (DORNFELD, 2006). Thus, ecotoxicological tests of sediments provide valuable information about the level of contamination and about the possible effects on the aquatic biota.

In this context, this study aimed to analyze metals contamination and assess the potential toxicity of sediments of water courses contaminated by metals using Chironomus xanthus as the test organism.

\section{MATERIAL AND METHODS \\ Study Area}

Sediments were collected in three streams previously analyzed for metal contamination (GUIMARÃES-SOUTO et al., 2014). In these streams, the occurrence of zinc, manganese, cadmium and copper (P1, P2 and P3) was recorded. Sediment was also collected in three points of the Uberabinha river, the main watercourse of the city of Uberlândia, in the state of Minas Gerais. Point 4 is located in the Sucupira water reservoir, the water supply source for Uberlândia. Point 5 is located in a densely urbanized section of the river (confluence of the Uberabinha with Liso stream) and point 6 is located downstream of the sewage treatment station - ETE Uberabinha (Figure 1).

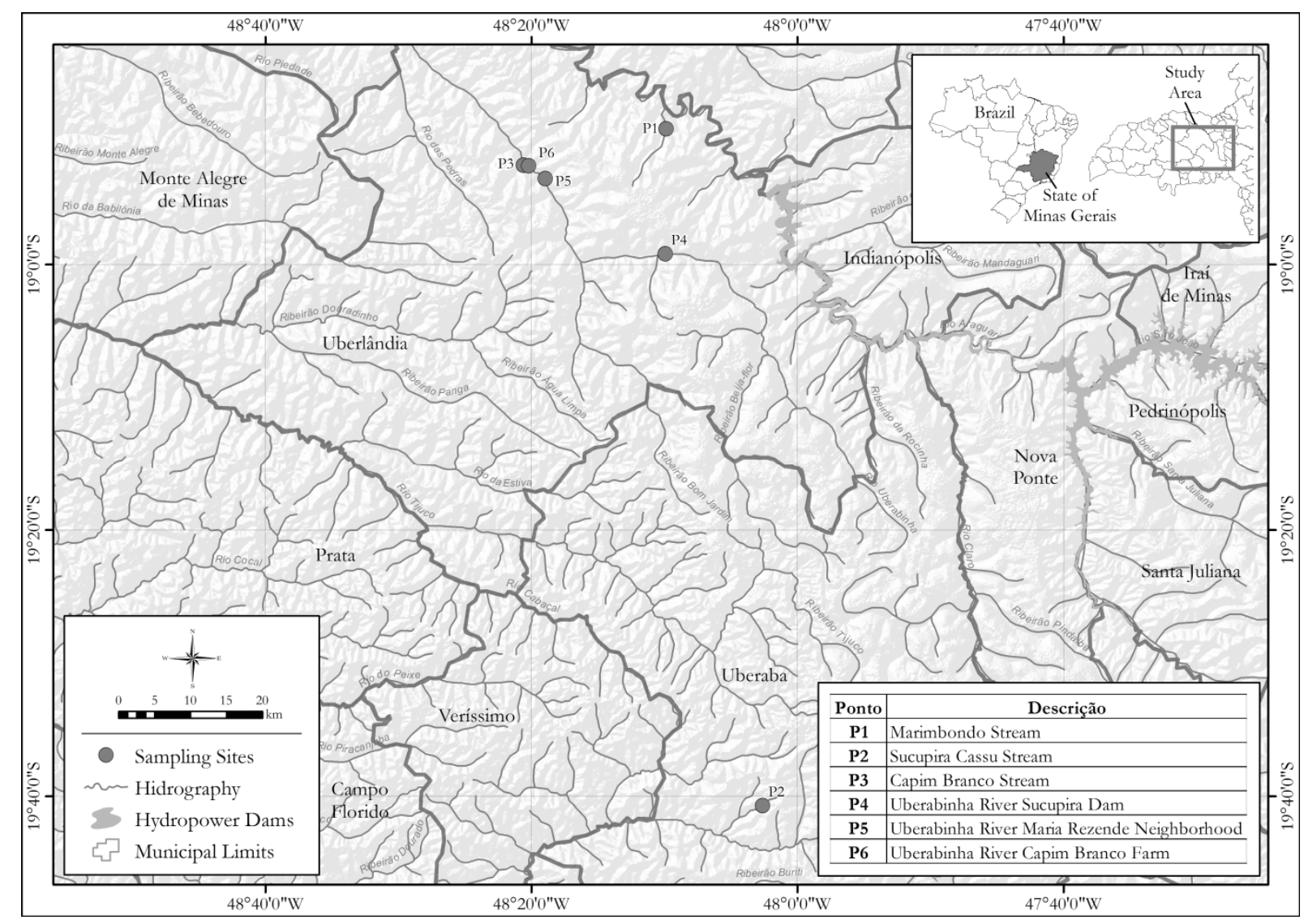

Figure 1. Localization of the sampling sites.

\section{Sediment Sampling for Toxicity Bioassays and Metal Analysis}

At each sampling point, two sediment samples were collected using a plastic spatula. Each sample was composed of sediments from the right and left watercourse edges, each with a volume of $500 \mathrm{~mL}$. The samples were packed in plastic pots, transported to the laboratory under refrigeration (in an isothermal box with ice) and maintained at $4{ }^{\circ} \mathrm{C}$ until analysis. Sediments were collected in December / 2013 and, as proposed by Burton-Jr (1992), the toxicity bioassays (January / 2014) did not exceed the maximum time of six weeks after the material collection. 


\section{Sediment Metal Analysis}

Metal analyses were conducted following the methodology described by Corbi et al. (2010) and adapted to the weight of the sediment samples. About $3.0 \mathrm{~g}$ of sediment in natura were placed in a $100 \mathrm{ml}$ beaker, and then $5.0 \mathrm{ml}$ of nitric acid solution and $5.0 \mathrm{~mL}$ of distilled water were added. The mixture was kept for 2 hours in a shaking table with horizontal circular motion rotation at $200 \mathrm{rpm}$. The material was filtered on Whatman 42 filter paper and then transferred to $50 \mathrm{ml}$ volumetric flasks which were kept at $4^{\circ} \mathrm{C}$ until analysis. The extracts of total metal were analyzed by atomic absorption spectrophotometry (PyeUnicam) (Perkin Elmer Analyst 300).

Metal concentrations were compared with the Canadian Environmental Quality Guidelines Protocol (EQGs), which establishes guide values for the concentration of metals in sediments. According to this protocol, TEL (Threshold Effect Level) and PEL (Probable Effect Level) concentrations which reflect the likelihood of deleterious effects on biota are due to its exposure to these concentration levels. The TEL value represents the concentration below which adverse effects to aquatic organisms are rarely expected. The high limit (PEL), on the other hand, is the concentration above which adverse effects on the organisms are often expected. In the range between TEL and PEL are values in which such effects are expected to occur (SILVÉRIO, 2003). Also, EUT values were considered (Effects Upper Threshold), indicating levels above which adverse biological effects are expected (BUCHMAN, 1999).

\section{Larvae Cultivation}

The Chironomus xanthus species was chosen because it is easily obtained and maintained in laboratory culture (DORNFELD, 2006) and because it has been widely used in ecotoxicological studies (FONSECA, 1997; PAMPLIM, 1999; DORNFELD, 2002; 2006; CAVALCANTI, 2010). The larvae were derived from Chironomus xanthus cultures of Biological Processes Laboratory (LPB) USP / São Carlos. The C. xanthus life cycle lasts an average of 14 days and may vary from 12 to 16 days (SANTIAGO, 2012).

\section{Acute Toxicity Tests}

The acute toxicity test was conducted using the methodology described in Fonseca (1997), which consists of exposing six organisms of IV instar in $60 \mathrm{~g}$ of sediment and $240 \mathrm{ml}$ of deionized water. For each sampling point, bioassays were performed in triplicates. New plastic pots $(500 \mathrm{~mL})$ were used for testing. The temperature was maintained in the range of 23 to $27^{\circ} \mathrm{C}$ and photoperiod of $12 / 12$ hours. The larvae were fed with Tetramin ${ }^{\circledR}(20 \mathrm{ml}$ per pot $)$ at a concentration of $2 \mathrm{~g} / 1000 \mathrm{ml}$ of distilled water. Test analyses were performed after 96 hours and living organisms were recorded. The sites were categorized into toxic (death $>50 \%)$, toxicity signs $(10<$ mortality < $50 \%$ ) and non-toxic (mortality $<10$ ), as proposed by Barbosa (2000). This test was also performed in triplicate in control sediment (inert sand subjected to furnace - temperature of approximately $400^{\circ} \mathrm{C}$ - for a period of 4 hours).

The water used for the tests had the following physical and chemical characteristics: Conductivity between 25-55 $\mu \mathrm{S} \mathrm{cm}^{-1}$, hardness between 12 and $16 \mathrm{mg} \mathrm{L}^{-1}$ for $\mathrm{CaCO}_{3}$, $\mathrm{pH}$ between 6.5 and 7.5 and temperature of $22 \pm 2^{\circ} \mathrm{C}$.

\section{Chronic Toxicity Tests}

For the chronic toxicity test, the same procedures for the acute toxicity bioassay were conducted, but using larvae of the second instar: generally young larvae (first and second instar) are more sensitive than the third and fourth larvae instar (EBAU et al., 2012).

The permanence of the larvae in contact with the sediment had a duration of nine days, and the samples were continuously aerated. The larvae were fed with Tetramin ${ }^{\circledR}$ and distilled water at a ratio of $2 \mathrm{~g} / 1000 \mathrm{ml}$. In each pot, $20 \mathrm{ml}$ of this solution were added every 2 days. At the end of the experiment, the surviving larvae were quantified and stored for later body size measurements (longitudinal axis). The measurements were conducted using a stereomicroscope and ocular micrometer. This test was also performed in triplicate in the control sediment using inert sand subjected to furnace at temperature of approximately $400^{\circ} \mathrm{C}$ for a period of 4 hours according to the methodology proposed by CALLISTO; ESTEVES (1996).

The larvae body length data and the control sediment were compared with the Analysis of Variance (ANOVA) using the statistical program Systat 12.

\section{RESULTS AND DISCUSSION}

\section{Metals in Sediments}

All metals were found in the six sampling points. Metal analyses in sediment control (Control CTR) showed the absence of magnesium and copper and very low levels of zinc, manganese and chromium (Table 1). 
The lowest concentration was recorded for chromium (Cr), and in all sampling points the levels were lower than TEL. The presence of chromium is related to tanneries, fertilizers and ceramics industries, manufacture of paints and pigments, wood preservative and electroplating (CETESB, 2012a). Low $\mathrm{Cr}$ levels found in this study are probably related to the absence of these activities in the studied water systems. Manganese contents ranged from 87 to $873.3 \mathrm{mg} / \mathrm{kg}$, and all values less than EUT Manganese is an essential nutrient in small quantities to many living organisms, including humans, particularly in reproductive processes, maintaining bone structure and function of the nervous system (CETESB, 2014). For magnesium, the concentration ranged from 163.3 to $578 \mathrm{mg} / \mathrm{kg}$. There are still no reference values for this element.

Copper concentration values detected were between TEL and PEL at the three sampling points: P1, P3 and P6. Whereas contamination by $\mathrm{Cu}$ can arise in domestic and industrial sewage or leachate agricultural products through rain (PELÁEZRODRÍGUES, 2001; CORBI et al., 2006), $\mathrm{Cu}$ values in the intervals between TEL and PEL reflect the presence of pollution sources at the points P1, P3 and P6. These watercourses are probably subjected to illegal waste dumps from urban areas. These same watercourses also have sections in rural areas possibly receiving fertilizer residues used in agriculture, which may be rich in metals (MORAES, 2009). Zinc was found in high concentration - above EUT - in P6. According to Poleto and Castilho (2008), the main sources of $\mathrm{Zn}$ are tire wear, automotive oils, galvanized materials, abrasion vehicles, hydraulic fluids and industrial effluents. This point located after the wastewater treatment plant receives waste from upstream areas subject to numerous impacts: agriculture, industrial effluents and urban areas.

High concentrations of zinc in sediments can cause deleterious effects to aquatic life. In fish species Catostomus commersoni (Catostomidae) it can reduce the development and also in invertebrates it can suppress the occurrence of sensitive groups such as Plecoptera, Ephemeroptera, Trichoptera and amphipods (MUNKITTRICK et al., 1991; EISLER, 1993; USDOI, 1998).

Table 1. Determination of metals in sediment samples ( $\left.\mathrm{mg} \mathrm{Kg}^{-1}\right)$. Bold values above UET; underscores, values between TEL and PEL.

\begin{tabular}{llllll}
\hline \multicolumn{1}{c}{ Samples } & Zn & Cu & Mn & Mg & Cr \\
\hline Control & 1.100 & 0 & 0.05 & 0 & 0.005 \\
P1 & 57.917 & $\underline{67.833}$ & 873.333 & 395.166 & 1.265 \\
P2 & 11.150 & 6.65 & 87 & 222.333 & 12.34 \\
P3 & 41.367 & $\underline{45.95}$ & 233.166 & 249.166 & 1.396 \\
P4 & 33.916 & 28.3 & 273.333 & 163.333 & 1.658 \\
P5 & 28.150 & 18.133 & 190.166 & 214.5 & 0.647 \\
P6 & $\mathbf{7 9 9 . 1 6 6}$ & $\underline{47.766}$ & 112.166 & 578 & 1.074 \\
TEL & 123.100 & 35.7 & - & - & 37.3 \\
PEL & 315.000 & 197 & - & - & 90 \\
UET & 520 & 86 & 1100 & - & 95 \\
\hline
\end{tabular}

\section{Acute Toxicity Bioassays}

Four points in this study (P1, P2, P4 and P5) were classified as evidence of toxicity and two points (P3, P6) as toxic, according to the classification of Barbosa (2000) (Table 2).

Toxicity is possibly related to the concentration of metals in sediments at points 1,3 and 6 , in which metal contents above TEL were found. However, a number of other compounds not evaluated in this study can adversely affect the survival of aquatic organisms such as organochlorines and persistent toxic substances in general, dioxins, organophosphates, phenols (HEWITT et al., 1996; SANTOS, 2009; CETESB, 2012b) among many other substances in domestic and industrial effluents.

In this study, the acute toxicity of points 3 and 6 stands out, and had 72.22\% and 100\% mortality, respectively. Possibly in these watercourses deleterious implications of sediment contamination occur in the aquatic fauna, especially for the community of benthic macroinvertebrates, which respond directly to surrounding environmental quality (KARR, 1991; ROSEMBERG; RESH, 1993). Guimarães-Souto (2014) found a high diversity of aquatic insects in point 3, such as Leptophlebiidae (mayfly) and Lepidoptera, groups considered very sensitive to 
environmental degradation. The findings of this study point indicates the risk of impact on these groups, which are highly sensitive to environmental pollution.

Another point was the evidence of toxicity found in the P4 sediments, the Sucupira reservoir, which is the main source of water supply for the city of Uberlândia, in the state of Minas Gerais. Although with low metal concentrations, other pollutants may be present, such as 4.4 DDE, a type of organochlorate that was found in the sediment at this point, in concentrations above the maximum limit allowed (see GUIMARÃESSOUTO et al., 2014)

Table 2. Acute toxicity of sediment for Chironomus xanthus species. Mortality average percentage $(n=3)$.

\begin{tabular}{lll}
\hline Samples & \% Mortality & Toxicity \\
\hline Control & 11.1 & No toxicity \\
P1 & 27.78 & Evidence of toxicity \\
P2 & 27.78 & Evidence of toxicity \\
P3 & 72.22 & Toxic \\
P4 & 27.78 & Evidence of toxicity \\
P5 & 27.78 & Evidence of toxicity \\
P6 & 100 & Toxic \\
\hline
\end{tabular}

\section{Chronic Toxicity Bioassays}

The survival rate ranged from $77.77 \%$ (point 3) to zero (point 6). These results corroborate the acute toxicity data indicating high toxicity of the sediments, particularly in P6, in which the mortality rate was $100 \%$ (Table 3 ).

Table 3. Bioassay result of chronic toxicity - average percentage of survival $(n=3)$

\begin{tabular}{|c|c|}
\hline Samples & \% Survival \\
\hline Control & 88.90 \\
\hline Point 1 & 55.55 \\
\hline Point 2 & 50.00 \\
\hline Point 3 & 77.77 \\
\hline Point 4 & 27.77 \\
\hline Point 5 & 55.55 \\
\hline Point 6 & 0 \\
\hline $\begin{array}{l}\text { While growth is widely used as a parameter } \\
\text { for the study of chronic toxicity for general } \\
\text { pollutants (KOSALWAT; KNIGHT, 1987), in this } \\
\text { study no significant differences were found in } \\
\text { relation to body size (Figure } 2 \text { ). However, all larvae } \\
\text { are significantly larger than the control ( } \mathrm{F}_{5,61}= \\
19.103 \text {, p< } 0.000 \text { ) which may be due to the organic } \\
\text { matter present in the sediments. } \\
\text { The high mortality of Chironomus xanthus } \\
\text { larvae exposed to sediment also indicates the } \\
\text { toxicity to this species. This pattern can be inferred } \\
\text { to other benthic macroinvertebrates, especially the } \\
\text { most sensitive, such as Ephemeroptera, Plecoptera }\end{array}$ & $\begin{array}{l}\text { negative changes in water quality have their } \\
\text { richness reduced (WALLACE; ANDERSON, 1996; } \\
\text { BUENO; BOND-BUCKUP; FERREIRA, 2003) and } \\
\text { may cause impoverishment of species (Karp et al., } \\
\text { 2012). } \\
\text { Considering these issues, monitoring the } \\
\text { sediment quality in the Triângulo Mineiro streams is } \\
\text { of fundamental importance for the maintenance of } \\
\text { aquatic biodiversity and for environmental quality. } \\
\text { We also emphasize the need for special attention in } \\
\text { monitoring metals in the Sucupira reservoir, the } \\
\text { main source of water supply for the Uberlândia-MG } \\
\text { municipality. }\end{array}$ \\
\hline
\end{tabular}




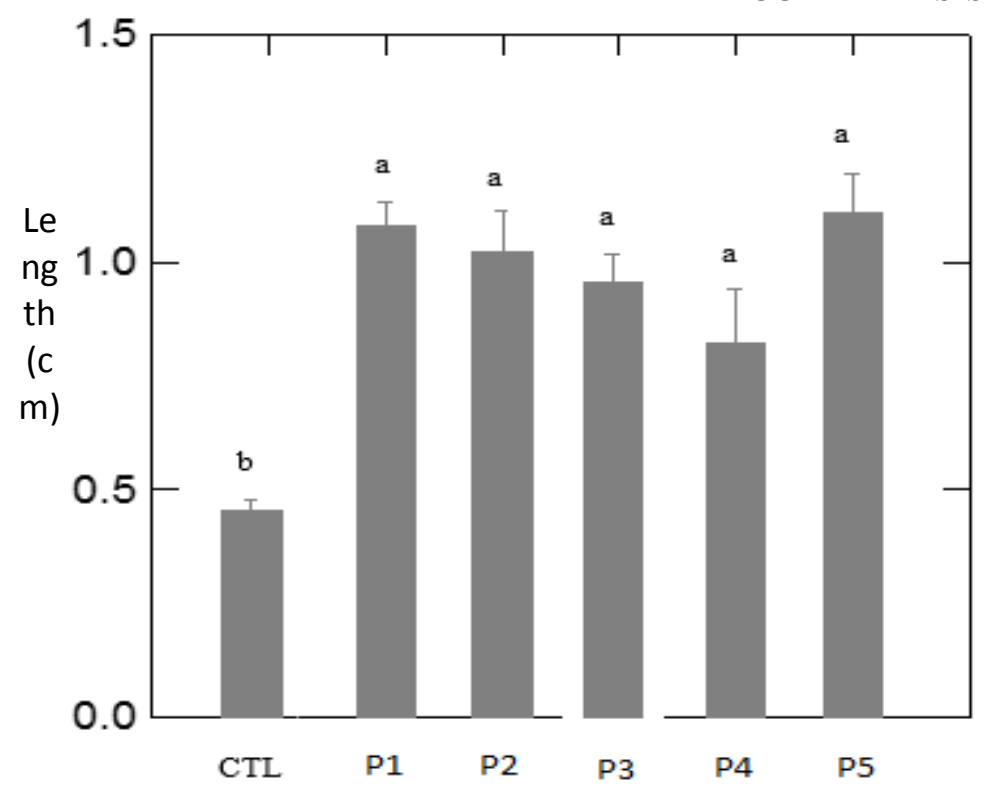

Figure 2. Body length of Chironomus xanthus submitted to the chronic toxicity test. CTL: control; P1 - Capim Branco stream; P2: Marimbondo stream, P3: Sucupira Cassu stream; P4: Uberabinha river - Maria Resende; P5: Uberabinha river - Sucupira reservoir. Different letters represent statistically significant difference.

\section{ACKNOWLEDGEMENTS}

Guimarães who greatly assisted in the construction of cages for the adult insects.

We thank all the researchers who assisted us in the field data collection, especially Mr. Walter

RESUMO: Este estudo objetivou avaliar a contaminação de metais nos sedimentos de cursos de água do Triângulo Mineiro e também analisar a toxicidade desses sedimentos utilizando larvas de Chironomus xanthus como organismo teste. Foram coletados sedimentos de três riachos (P1, P2 e P3) e também em três pontos do rio Uberabinha (P4, P5 e P6). Foram analisados $\mathrm{Cu}, \mathrm{Cr}, \mathrm{Mn}, \mathrm{Mg}$ e $\mathrm{Zn}$, e também realizados testes de toxicidade aguda e crônica. As amostras submetidas aos testes agudos foram categorizadas como tóxicas (mortalidade $>50 \%$ ), evidências de toxicidade (mortalidade entre $10 \%$ e $50 \%$ ) e não tóxicas (mortalidade <10\%). Nos testes de toxicidade crônica, as larvas sobreviventes foram armazenadas para medidas do tamanho corporal. Dos cinco metais analisados, todos foram encontrados nos seis pontos amostrais, mas apenas $\mathrm{Cu}$ e $\mathrm{Zn}$ estavam presentes em níveis mais altos que TEL - Threshold Effect Level. Os sedimentos dos seis locais apresentam toxicidade ou indício de toxicidade e a mortalidade nos testes de toxicidade aguda e crônica foi de $100 \%$. Não foram encontradas diferenças estatisticamente significativas, entre o tratamento e o controle, no crescimento larval. Com base na contaminação verificada e nos resultados dos bioensaios de toxicidade, consideramos importante monitorar os sedimentos e as mudanças no uso dos solos adjacentes aos cursos de água.

PALAVRAS-CHAVE: Toxicidade aguda. Toxicidade crônica. Tamanho corporal. Zinco.

\section{REFERENCES}

AMBUMOZHI, V., RADHAKRISHNAN, J., YAMAJI, E. Impact of riparian buffer zones on water quality and associated management considerations. Ecological Engineering, v. 24, p. 517-523. 2005. https://doi.org/10.1016/j.ecoleng.2004.01.007

AMISAH, S.; COWX, I. G. Impacts of abandoned mine and industrial discharges on fish abundance and macroinvertebrate diversity of the upper River Don in South Yorkshire, UK. Journal of Freshwater Ecology, v. 15, n. 2, p. 237-250. 2000. https://doi.org/10.1080/02705060.2000.9663741 
ANGELOTTI-NETTO, A.; CRESTANA, S.; DE OLIVEIRA, S. C.; BARBOSA, R. V. R. Metais pesados provenientes de atividade agrícola: formas, prevenção e controle. In: ESPÍNDOLA, E. L. G.; WENDLAND, E. (Eds.). Bacia hidrográfica. São Carlos: RiMa, 2004. p. 1-14.

ARIAS, A. R. L.; BUSS, D. F.; ALBURQUERQUE, C. DE; INÁCIO, A. F.; FREIRE, M. M.; EGLER, M.; BAPTISTA, D. F. Utilização de bioindicadores na avaliação de impacto e no monitoramento da contaminação de rios e córregos por agrotóxicos. Revista Ciência \& Saúde Coletiva, Rio de Janeiro, v. 12, n. 1, p. 61-72, Jan/Mar. 2007.

BAPTISTA, I. E.; SOARES, C. H. L; MATIAS, W. G.; LOPES, E. B. Avaliação da toxicidade aguda de efluentes de uma indústria têxtil utilizando Daphnia magna, Poecilia reticulata e Vibrio fischeri como bioindicadores. In: ESPÍNDOLA, E. L. G.; PASCHOAL, C. M. R. B.; ROCHA, O.; BOHRER, M. B. C.; OLIVEIRA-NETO, A. L. (Eds.), Ecotoxicologia: Perspectivas para o século XXI. São Carlos: RiMa, 2002. p. 365-575.

BARBOSA, R. M. Avaliação do impacto de efluentes (lodos) de estações de tratamento de água à biota aquática através de testes de toxicidade. 2000. 199 f. Tese (Doutorado em Ciências da Engenharia Ambiental) Escola de Engenharia de São Carlos, Universidade de São Paulo, São Carlos, 2000.

BUCHMAN, M. F. NOAA Screening Quick Reference Tables, NOAA HAZMAT, Report 99-1. Seattle: Coastal Protection and Restoration Division, National Oceanic and Atmospheric Administration, 1999. 12 p.

BUENO, A. A. P.; BOND-BUCKUP, G.; FERREIRA, B. D. P. Estrutura da comunidade de invertebrados bentônicos em dois cursos d'água do Rio Grande do Sul, Brasil. Revista Brasileira de Zoologia, Curitiba, v. 20, n. 1, p. 115-125, Mar. 2003. https://doi.org/10.1590/S0101-81752003000100014

BUIKEMA, A. L.; VOSHELL, J. R. Toxicity studies using freshwater benthic macroinvertebrates. In: ROSENBERG, D. M., RESH, V. H. (Eds.). Freshwater Biomonitoring and Benthic Macroinvertebrates. New York: Chappman \& Hall, 1993. p. 344-398.

BURTON-Jr, G. A. Sediment toxicity assessment. Florida: Lewis Publishers, 1992. 480 p.

CASPER, A. F. Population and community effects of sediment contamination from residential urban runoff on benthic macroinvertebrate biomass and abundance. Bulletin of Environmental Contamnination and Toxicology, New York, v. 53, n. 6, p. 796-799, Dec. 1994. https://doi.org/10.1007/BF00196206

CALLISTO, M.; ESTEVES, F. A. Composição granulométrica do sedimento de um lago amazônico impactado por rejeito de bauxita e um lago natural. Acta Limnologica Brasiliensia, Rio Claro, v. 8, p. 115-126, 1996.

CAVALCANTI, V. A. Avaliação da toxicidade de sedimentos e águas contaminadas com azocorantes têxteis utilizando Chironomus xanthus e Daphnia similis. 2010. 66 f. Dissertação (Mestrado) - Escola Nacional de Saúde Pública Sérgio Arouca, ENSP, Fundação Osvaldo Cruz, Rio de Janeiro, 2010.

COMPANHIA AMBIENTAL DO ESTADO DE SÃO PAULO (CETESB). Ficha de Informação Toxicológica (FIT): Cromo. São Paulo, SP. 2012a. Disponível em: $<$ <ttp://www.cetesb.sp.gov.br/userfiles/file/agua/aguas.../aguas.../cromo.pdf >. Acesso em: 05 Mar. 2012.

COMPANHIA AMBIENTAL DO ESTADO DE SÃO PAULO (CETESB). Alterações Físicas e Químicas: Contaminantes: Fenol. São Paulo, SP. 2012b. Disponível em:

$<$ http://www.cetesb.sp.gov.br/mortandade/causas_contaminantes_fenol.php>. Acesso em: 12 Mar. 2012.

COMPANHIA AMBIENTAL DO ESTADO DE SÃO PAULO (CETESB). Ficha de Informação

Toxicológica (FIT): Manganês. São Paulo, SP. 2014. Disponível em: < https://cetesb.sp.gov.br/laboratorios/wp-content/uploads/sites/24/2013/11/Mangan\%C3\%AAs.pdf >. Acesso em: 05 Mar. 2014. 
CORBI, J. J.; TRIVINHO-STRIXINO, S.; DOS SANTOS, A.; DEL GRANDE, M. Diagnóstico ambiental de metais e organoclorados em córregos adjacentes a áreas de cultivo de cana-de-açúcar (estado de São Paulo, Brasil). Química Nova, São Paulo, v. 2, n. 1, p. 61-65. 2006. https://doi.org/10.1590/S010040422006000100013

CORBI, J. J.; FROEHLICH, C. G.; STRIXINO, S. T.; SANTOS, A. Bioaccumulation of metals in aquatic insects of streams located in areas with sugar cane cultivation. Química Nova, São Paulo, v. 33, n. 3, p. 644648. 2010. https://doi.org/10.1590/S0100-40422010000300030

CORBI, J. J.; GEROMEL-COSTA, C. G. A.; COLOMBO, V; GORNI, G. R.; RIOS, L. Environmental diagnosis of metals in streams near sugarcane cultivation areas: current and historical analysis in the central region of the State of São Paulo. Anais da Academia Brasileira de Ciências, v. 90, n. 3, p. 2018.

COSTA, C. R.; OLIVI, P.; BOTTA, C. M. R.; ESPINDOLA, E. L. G. A toxicidade em ambientes aquáticos: discussão e métodos de avaliação. Química Nova, São Paulo, v. 31, n. 7, p. 1820-1830. 2008. https://doi.org/10.1590/S0100-40422008000700038

DORNFELD, C. B. Utilização de análises limnológicas e bioensaios toxicológicos em macroinvertebrados bentônicos para o diagnóstico ambiental do reservatório de Salto Grande (Americana - SP). 2002. 196 f. Dissertação (Mestrado) - Escola de Engenharia de São Carlos, Universidade de São Paulo, São Carlos, 2002.

DORNFELD, C. B. Utilização de Chironomus sp. (Diptera, Chironomidae) para avaliação da qualidade de sedimentos e contaminação por metais. 2006. 211 f. Tese (Doutorado em Ciências da Engenharia Ambiental) Escola de Engenharia de São Carlos, Universidade de São Paulo, São Carlos, 2006.

EBAU, W.; RAWI, C. S. M.; DIN, Z.; AL-SHAMI, S. A. Toxicity of cadmium and lead on tropical midge larvae, Chironomus kiiensis Tokunaga and Chironomus javanus Kieffer (Diptera: Chironomidae). Asian Pacific Journal of Tropical Biomedicine, v. 2, n. 8, p. 631-634, Aug. 2012. https://doi.org/10.1016/S22211691(12)60110-5

EISLER, R. Zinc hazards to fish, wildlife, and invertebrates: a synoptic review. Laurel MD: Department of the Interior, Fish and Wildlife Service, 1993. 126 p.

FONSECA, A. L. Avaliação da qualidade da água do rio Piracicaba/SP através de testes de toxicidade com invertebrados. 1997. 211 f. Tese (Doutorado em Ciências da Engenharia Ambiental) - Escola de Engenharia de São Carlos, Universidade de São Paulo, São Carlos, 1997.

GUIMARÃES-SOUTO, R. M. O papel da contaminação por compostos organoclorados e metais na ecologia de macroinvertebrados bentônicos. 2014. 66 f. Tese (Doutorado em Ecologia e Conservação de Recursos Naturais) - Instituto de Biologia, Universidade Federal de Uberlândia, Uberlândia, 2014.

GUIMARÃES-SOUTO, R. M.; CORBI, J. J.; JACOBUCCI, G. B. Diagnóstico ambiental de Organoclorados em sedimentos e invertebrados bentônicos de bacias hidrográficas do Triangulo Mineiro, Minas Gerais, Brasil. Revista Brasileira de Recursos Hídricos, v. 19, n. 1, p. 143-153, Jan/Mar. 2014. https://doi.org/10.21168/rbrh.v19n1.p143-153

HEWITT, L. M.; CAREY, J. H.; DIXON, D. G.; MUNKITTRICK, K. R. Examination of bleached kraft mill effluent fractions for potential indices of mixed function oxygenase activity in rainbow trout. In: SERVOS, M. R. (Ed.). Environmental Fate and Effects of Pulp and Paper Mills Effluents. Florida: St. Lucie Press, 1996. p. 79-93.

KARP, D. S., ROMINGER, A. J., ZOOK, J., RANGANATHAN, J., EHRLICH, P. R.; DAILY, G. C. Intensive agriculture erodes beta-diversity at large scales. Ecology. Letters, v.15, p. 963-970, Sep. 2012. https://doi.org/10.1111/j.1461-0248.2012.01815.x 
KARR, J. Biological integrity: a long neglected aspect of water resource management. Ecological Applications, New York, v. 1, n. 1, p. 66-84, Feb. 1991. https://doi.org/10.2307/1941848

KOSALWAT, P.; KNIGHT, A. Chronic toxicity of copper to a partial life cycle of the midge, Chironomus decorus. Archives of Environmental Contamination and Toxicology, NewYork, v. 16, n. 3, p. 283-290, May. 1987.

MATEO-SAGASTA, J.; ZADEH, S. M.; TURRAL, H. Water pollution from agriculture: a global review. Rome, 2017. Disponível em: < http://www.fao.org/3/a-i7754e.pdf >. Acesso em 13 Ago. 2018.

MORAES, M. F. de Micronutrientes e metais pesados tóxicos: do fertilizante ao produto agrícola. 2009. $108 \mathrm{f}$. Tese (Doutorado em Ciências, área de Energia Nuclear na Agricultura e no Ambiente) - Centro de Energia Nuclear na Agricultura, Universidade de São Paulo, Piracicaba, 2009.

MUNKITTRICK, K. R.; MILLER, P. A.; BARTON, D. R.; DIXON, D. G. Altered performance of white sucker population in the Manitouwadge chain of lakes is associated with changes in benthic macroinvertebrates communities as a result of copper and zinc contamination. Ecotoxicology and Environmental Safety, v. 21, n. 3, p. 318-326, Jun, 1991. https://doi.org/10.1016/0147-6513(91)90071-V

PAMPLIM, P. A. Z. Avaliação da qualidade ambiental da represa de Americana (SP - Brasil) com ênfase no estudo da comunidade de macroinvertebrados bentônicos e parâmetros ecotoxicológicos. 1999. 88f.

Dissertação (Mestrado) - Escola de Engenharia de São Carlos, Universidade de São Paulo, São Carlos, 1999.

PARRIS, K. Environmental impacts in the agricultural sector: using indicator as a tool for policy purposes. Montreal, CA. 2002. Disponível em: <http://www.cec.org/files/pdf/economy/OECDParris_EN.pdf>. Acesso em: 06 Mar. 2002.

PELÁEZ-RODRÍGUEZ, M. Avaliação da qualidade da água da Bacia do Alto Jacaré-Guaçu/SP (Ribeirão do Feijão e Rio do Monjolinho) através de variáveis físicas, químicas e biológicas. 2001. 145 f. Tese (Doutorado em Ciências da Engenharia Ambiental) - Escola de Engenharia de São Carlos, Universidade de São Paulo, São Carlos, 2001.

POLETO, C.; CASTILHO, Z. C. Impacto por poluição difusa de sedimentos em bacias urbanas. In: POLETO, C. (Ed.). Ambiente e Sedimentos. Porto Alegre: ABRH, 2008. p. 193-227.

ROSEMBERG, D. M.; RESH, V. H. Freshwater biomonitoring and benthic macroinvertebrates. New York: Chappman \& Hall, 1993. 488 p.

SANTIAGO, L. L. Avaliação dos efeitos genotóxicos e de acumulação induzidos pela cilindrospermopsina (cianotoxina) em Chironomus xanthus (Diptera - Chironomidae). 2012. 67f. Dissertação (Mestrado em Meio Ambiente e Recursos Hídricos) - Instituto de Recursos Naturais, Universidade Federal de Itajubá, Itajub, 2012.

SANTOS, E. R. Caracterização química, microbiológica e toxicidade do lodo de esgoto da Estação Mangueira, Pernambuco, Brasil. 2009. 68 f. Dissertação (Mestrado em Desenvolvimento de Processos Ambientais), Universidade Católica de Pernambuco, Recife, 2009.

SILVÉRIO, P. F. Bases técnico-científicas para a derivação de valores-guia de qualidade de sedimentos para metais: Experimentos de campo e laboratório. 2003. 145 f. Tese (Doutorado em Ciências da Engenharia Ambiental) - Escola de Engenharia de São Carlos, Universidade de São Paulo, São Carlos, 2003.

SPSS. SYSTAT 12 Statistics I \& II. SPSS, Inc., Chicago, IL. 2007.

UNEP. A snapshot of the world's water quality: towards a global assessment. Nairobi, United Nations Environment Programme (UNEP). 2016. Disponível em: < https://uneplive.unep.org/media/docs/assessments/unep_wwqa_report_web.pdf>. Acesso em 13 Ago. 2018. 
UNITED STATES DEPARTMENT OF THE INTERIOR (USDOI). Guidelines for interpretation of the biological effects of selected constituents in biota, water, and sediment. Zinc. Information Report no. 3. USA: National Irrigation Water Quality Program, 1998.

ZIA, A.; HARRIS, N. R.; MERRETT, G. V.; RIVERS, M.; COLES, N. The impact of agricultural activities on water quality: A case for collaborative catchment-scale management using integrated wireless sensor networks. Computers and Electronics in Agriculture, v. 96, p. 126-138, Aug, 2013.

https://doi.org/10.1016/j.compag.2013.05.001

WALLACE, J. B.; ANDERSON, N. H. Habitat, life history, and behavioral adaptations of aquatic insects. In: MERRIT, R. W; CUMMINS, K. W. (Eds.). An introduction to the aquatic insects of North America. USA: Kendall/Hunt Publishing Company, 2 ed., 1996. p. 41-73. 